\title{
Synthesis and magnetic properties of one-dimensional metal oxalate networks as molecular-based magnets ${ }^{\dagger}$
}

\author{
B P SINGH and B SINGH* \\ Department of Chemistry, Faculty of Science, Banaras Hindu University, Varanasi 221 005, India
}

MS received 23 November 1998; revised 25 October 1999

\begin{abstract}
The homo- and heteropolymetallic assemblies of $\mathrm{MM}^{\prime}(\mathrm{OX})_{2}\left(\mathrm{H}_{2} \mathrm{O}\right)_{4}$, where $\mathrm{MM}^{\prime}$ represents $\mathrm{MnMn}$, CoMn, NiMn, CuMn, CoCo, NiCo, $\mathrm{CuCo}, \mathrm{NiNi}, \mathrm{CuNi}$, and $\mathrm{CuCu}$; and the respective complexes, numbered 1-10, have been prepared by reacting metal(II) salts-i.e. of $\mathrm{Mn}, \mathrm{Co}, \mathrm{Ni}$, and $\mathrm{Cu}-$ and potassium oxalate monohydrate in hot water $\left(90-100^{\circ} \mathrm{C}\right)$. The magnetic susceptibility data of the complexes 8 and 9 in the $300 \mathrm{~K}-20 \mathrm{~K}$ temperature range obeys the Curie-Weiss law and exhibits Weiss constants $-50 \mathrm{~K}$ and $-100 \mathrm{~K}$, respectively. On lowering the temperature, the effective magnetic moment decreases gradually and is indicative of antiferromagnetic phase transition. The complexes have also been characterized by ES mass spectrometry, infrared (IR), electronic, and electron spin resonance (ESR) spectra.
\end{abstract}

Keywords. Molecular-based magnets; magnetic properties; one-dimensional metal oxalate; synthesis and structure of metal-oxalates.

\section{Introduction}

Synthesis and characterization of the polymetallic complexes with a goal to report molecular ferromagnets have been subject of numerous studies in recent years (Miller et al 1986, 1988a, b; Pei et al 1986; Nakaozawa et al 1992; Kahn 1993, 1995; Miller and Epstein 1994). Ferromagnets can be described as assemblies having magnetic vectors constituting paramagnetic centres which are aligned parallel over a three-dimensional matrix. They should exhibit bulk properties, such as long-range magnetic ordering, with spontaneous magnetization below the critical temperature $\left(T_{\mathrm{c}}\right)$, preferably around room temperature. Molecular ferromagnets reported so far are based on one-dimensional chains as the constituents in which the magnetic vectors are assembled by ferromagnetic interaction. In these one-dimensional chain-based magnets, magnetic phase transition temperature $\left(T_{\mathrm{c}}\right.$ or $\left.T_{\mathrm{N}}\right)$ is governed by both intra- and interchain magnetic interactions, and remains low because these interactions are weak.

The occurrence of long-range magnetic ordering in lattices, composed of molecular transition metal complexes, has been attracting attention of the workers in the field of materials science. These compounds are of interest because they are insulating and, hence, frequently transparent, and offer the opportunity of creating novel

${ }^{\dagger}$ Most of the work was presented at the "5th IUMRS International Conference in Asia' held at IISc, Bangalore during October 13-16, 1998

*Author for correspondence lattice architectures. They also offer the chemists the opportunity to investigate how magnetic exchange interactions are propagated through extended polyatomic ligands.

In the search for molecular-based magnets, the oxalate ion is an attractive building block because its ambidentate coordinating ability enables it to form an exchange pathway between two metal ions. Discrete dimeric complexes have been synthesized to study the detail of the exchange process (Julve et al 1984; Pei et al 1989). But recently oxalate ions are used to create bi-metallic arrays that are infinite in two- or three-dimensions (Tanaki et al 1992; Descurtins et al 1994a). Magnetic exchange between moments localized on the two different metal ions may be ferro- or antiferromagnetic according to their respective electron configurations in conformity with the KanamoriGoodenough rules (Goodenough 1963). The lattice topologies may also be highly unusual, for example the hexagonal honeycomb type of structure in the case of twodimensional arrays are changed to helical structure in three-dimensional ones (Atovmyan et al 1993; Descurtins et al 1994b). Such materials may also be interesting by reason of their optical transparency, since this carries the possibilities of unusual optical phenomena (Bellitto and Day 1992) resulting from the onset of magnetic order. Finally, the synthetic opportunity to combine organic molecular species with inorganic complexes within the same lattice brings with it the chance of affecting very subtle influences on the ligand field symmetry through small changes in molecular packing.

In view of simplicity and potential magnetic interest, the oxalate ion has been used widely to construct transition metal containing clusters and arrays in the search 
for new molecular magnets. The synthesis of bimetallic assemblies and their magnetic and spectroscopic characterization are described in the present paper.

\section{Experimental}

Metal(II) chlorides (BDH) and potassium oxalate (E Merck) of AR grade were used as obtained.

\subsection{Synthesis of $\mathrm{K}_{2}\left[\mathrm{M}(\mathrm{OX})_{2}\left(\mathrm{H}_{2} \mathrm{O}\right)_{2}\right] \cdot 4 \mathrm{H}_{2} \mathrm{O}:\left(\mathrm{M}^{I I}=\mathrm{Mn}\right.$, $\mathrm{Co}, \mathrm{Ni}$ and $\mathrm{Cu}$ )}

To an aqueous solution $\left(10 \mathrm{~cm}^{3}\right)$ of $\mathrm{MCl}_{2} \cdot n \mathrm{H}_{2} \mathrm{O}(0 \cdot 05 \mathrm{mmol})$ at $\sim 90^{\circ} \mathrm{C}$ was added a solution $\left(20 \mathrm{~cm}^{3}\right)$ of $\mathrm{K}_{2} \mathrm{C}_{2} \mathrm{O}_{4} \mathrm{H}_{2} \mathrm{O}$ $(0.2 \mathrm{mmol})$ in hot water. The compounds crystallized on cooling the reaction solution to room temperature. The complexes were filtered, washed with cold water and dried under reduced pressure.

2.2 Synthesis of $\left[M^{\prime} M(O X)_{2}\left(H_{2} O\right)_{4}\right]:\left(M=M^{\prime}=M n^{I I}\right.$, $\mathrm{Co}^{I I}, \mathrm{Ni}{ }^{I I}$ and $\mathrm{Cu} u^{I I}$ )

To an aqueous solution $\left(10 \mathrm{~cm}^{3}\right)$ of $\mathrm{MCl}_{2} \cdot n \mathrm{H}_{2} \mathrm{O}(0 \cdot 05 \mathrm{mmol})$ at $\sim 90^{\circ} \mathrm{C}$ was added a hot $\left(90^{\circ} \mathrm{C}\right)$ solution of potassium oxalate monohydrate $(0.2 \mathrm{mmol})$ with stirring. In this hot solution a hot aqueous solution $\left(10 \mathrm{~cm}^{3}\right)$ of $\mathrm{M}^{\prime} \mathrm{Cl}_{2} \cdot n \mathrm{H}_{2} \mathrm{O}$ $(0.05 \mathrm{mmol})$ was added. After a few $\mathrm{min}$, the complexes precipitated out, which were filtered, washed with hot water and dried under reduced pressure.

\section{Analysis and physical measurements}

The metal content in the complexes was determined volumetrically by EDTA titration after removing organic moiety by treating with aquaregia followed by sulphuric acid. The compounds gave satisfactory $\mathrm{C}$ and $\mathrm{H}$ values (table 1).

The water content was determined by heating a known amount of the complexes to a constant weight at $110^{\circ} \mathrm{C}$, $120^{\circ} \mathrm{C}$, and $150^{\circ} \mathrm{C}$; and evaluating the loss in weight. The IR spectra of complexes were recorded in $\mathrm{KBr}$ disc and in Nujol on a Jasco-5300 spectrophotometer. Electronic spectra of complexes were recorded on a Shimadzu 160A spectrophotometer. The ESR spectra of the powder complexes were recorded at liquid nitrogen temperature on a Varian $\mathrm{X}$ band $\mathrm{E}_{4}$ spectrometer using TCNE as the $\mathrm{g}$ marker. The variable-temperature magnetic susceptibility measurements were carried out with a Faraday-balance magnetometer equipped with helium continuous flow cryostat in the

Table 1. Analytical data and general properties of the complexes.

\begin{tabular}{|c|c|c|c|c|c|c|c|c|c|}
\hline \multirow[b]{2}{*}{ Complex } & & \multirow{2}{*}{$\begin{array}{l}\text { Molecular } \\
\text { weight } \\
\text { (M.W.) }\end{array}$} & \multirow{2}{*}{$\begin{array}{l}\text { Yield } \\
(\%)\end{array}$} & \multirow{2}{*}{$\begin{array}{c}\text { Decomposition } \\
\text { temperature } \\
\left({ }^{\circ} \mathrm{C}\right)\end{array}$} & \multirow{2}{*}{$\begin{array}{l}\text { Magnetic } \\
\text { moment } \\
\text { (B.M.) }\end{array}$} & \multicolumn{4}{|c|}{ Found (calcd.) (\%) } \\
\hline & & & & & & M & $M^{\prime}$ & $\mathrm{C}$ & $\mathrm{H}$ \\
\hline $\begin{array}{l}{\left[\mathrm{MnMn}(\mathrm{OX})_{2}\left(\mathrm{H}_{2} \mathrm{O}\right)_{4}\right]} \\
\mathrm{C}_{4} \mathrm{H}_{8} \mathrm{O}_{12} \mathrm{Mn}_{2}\end{array}$ & (1) & $357 \cdot 92$ & 86 & 340 & $7 \cdot 83$ & $\begin{array}{l}15 \cdot 80 \\
(15 \cdot 35)\end{array}$ & $\begin{array}{c}15 \cdot 80 \\
(15 \cdot 35)\end{array}$ & $\begin{array}{c}13 \cdot 10 \\
(13 \cdot 42)\end{array}$ & $\begin{array}{c}2 \cdot 46 \\
(2 \cdot 55)\end{array}$ \\
\hline $\begin{array}{c}{\left[\mathrm{CoMn}(\mathrm{OX})_{2}\left(\mathrm{H}_{2} \mathrm{O}\right)_{4}\right]} \\
\mathrm{C}_{4} \mathrm{H}_{8} \mathrm{O}_{12} \mathrm{CoMn}\end{array}$ & (2) & $361 \cdot 90$ & 82 & 270 & $7 \cdot 73$ & $\begin{array}{c}15 \cdot 94 \\
(16 \cdot 28)\end{array}$ & $\begin{array}{l}15 \cdot 03 \\
(15 \cdot 18)\end{array}$ & $\begin{array}{c}13 \cdot 60 \\
(13 \cdot 28)\end{array}$ & $\begin{array}{c}2 \cdot 63 \\
(2 \cdot 23)\end{array}$ \\
\hline $\begin{array}{c}{\left[\mathrm{NiMn}(\mathrm{OX})_{2}\left(\mathrm{H}_{2} \mathrm{O}\right)_{4}\right]} \\
\mathrm{C}_{4} \mathrm{H}_{8} \mathrm{O}_{12} \mathrm{NiCo}\end{array}$ & (3) & $361 \cdot 66$ & 90 & 280 & $5 \cdot 61$ & $\begin{array}{c}16 \cdot 79 \\
(16 \cdot 23)\end{array}$ & $\begin{array}{l}15 \cdot 06 \\
(15 \cdot 19)\end{array}$ & $\begin{array}{c}13 \cdot 57 \\
(13 \cdot 28)\end{array}$ & $\begin{array}{c}2 \cdot 01 \\
(2 \cdot 23)\end{array}$ \\
\hline $\begin{array}{c}{\left[\mathrm{CuMn}(\mathrm{OX})_{2}\left(\mathrm{H}_{2} \mathrm{O}\right)_{4}\right]} \\
\mathrm{C}_{4} \mathrm{H}_{8} \mathrm{O}_{12} \mathrm{CuCo}\end{array}$ & (4) & $366 \cdot 52$ & 76 & 290 & $4 \cdot 88$ & $\begin{array}{l}17 \cdot 60 \\
(17 \cdot 34)\end{array}$ & $\begin{array}{l}14.45 \\
(14.98)\end{array}$ & $\begin{array}{c}12 \cdot 98 \\
(13 \cdot 11)\end{array}$ & $\begin{array}{c}2 \cdot 48 \\
(2 \cdot 19)\end{array}$ \\
\hline $\begin{array}{c}{\left[\mathrm{CoCo}(\mathrm{OX})_{2}\left(\mathrm{H}_{2} \mathrm{O}\right)_{4}\right]} \\
\mathrm{C}_{4} \mathrm{H}_{8} \mathrm{O}_{12} \mathrm{Co}_{2}\end{array}$ & (5) & $365 \cdot 89$ & 79 & 290 & $6 \cdot 69$ & $\begin{array}{l}16 \cdot 42 \\
(16 \cdot 16)\end{array}$ & $\begin{array}{c}16 \cdot 53 \\
(16 \cdot 10)\end{array}$ & $\begin{array}{c}13 \cdot 52 \\
(13 \cdot 13)\end{array}$ & $\begin{array}{c}2 \cdot 38 \\
(2 \cdot 20)\end{array}$ \\
\hline $\begin{array}{l}{\left[\mathrm{NiCo}(\mathrm{OX})_{2}\left(\mathrm{H}_{2} \mathrm{O}\right)_{4}\right]} \\
\quad \mathrm{C}_{4} \mathrm{H}_{8} \mathrm{O}_{12} \mathrm{NiCo}\end{array}$ & (6) & $365 \cdot 65$ & 74 & 340 & $4 \cdot 67$ & $\begin{array}{c}16 \cdot 35 \\
(16 \cdot 12)\end{array}$ & $\begin{array}{c}16 \cdot 38 \\
(16 \cdot 05)\end{array}$ & $\begin{array}{c}13 \cdot 52 \\
(13 \cdot 14)\end{array}$ & $\begin{array}{c}2 \cdot 42 \\
(2 \cdot 12)\end{array}$ \\
\hline $\begin{array}{c}{\left[\mathrm{CuCo}(\mathrm{OX})_{2}\left(\mathrm{H}_{2} \mathrm{O}\right)_{4}\right]} \\
\mathrm{C}_{4} \mathrm{H}_{8} \mathrm{O}_{12} \mathrm{CuCo}\end{array}$ & (7) & $370 \cdot 51$ & 73 & 340 & $4 \cdot 52$ & $\begin{array}{c}17 \cdot 67 \\
(17 \cdot 15)\end{array}$ & $\begin{array}{c}15 \cdot 75 \\
(15 \cdot 90)\end{array}$ & $\begin{array}{c}12 \cdot 78 \\
(12 \cdot 96)\end{array}$ & $\begin{array}{c}2 \cdot 06 \\
(2 \cdot 18)\end{array}$ \\
\hline $\begin{array}{l}{\left[\mathrm{NiNi}(\mathrm{OX})_{2}\left(\mathrm{H}_{2} \mathrm{O}\right)_{4}\right]} \\
\quad \mathrm{C}_{4} \mathrm{H}_{8} \mathrm{O}_{12} \mathrm{Ni}_{2}\end{array}$ & (8) & $365 \cdot 41$ & 68 & 330 & $3 \cdot 37$ & $\begin{array}{c}16 \cdot 58 \\
(16 \cdot 06)\end{array}$ & $\begin{array}{c}16 \cdot 27 \\
(16 \cdot 06)\end{array}$ & $\begin{array}{c}13 \cdot 41 \\
(13 \cdot 15)\end{array}$ & $\begin{array}{l}2 \cdot 06 \\
(2 \cdot 20)\end{array}$ \\
\hline $\begin{array}{l}{\left[\mathrm{CuNi}(\mathrm{OX})_{2}\left(\mathrm{H}_{2} \mathrm{O}\right)_{4}\right]} \\
\mathrm{C}_{4} \mathrm{H}_{8} \mathrm{O}_{12} \mathrm{CuNi}\end{array}$ & (9) & $370 \cdot 27$ & 81 & 320 & $3 \cdot 47$ & $\begin{array}{c}17 \cdot 49 \\
(17 \cdot 16)\end{array}$ & $\begin{array}{l}15 \cdot 67 \\
(15 \cdot 85)\end{array}$ & $\begin{array}{c}12 \cdot 72 \\
(12 \cdot 98)\end{array}$ & $\begin{array}{c}2 \cdot 37 \\
(2 \cdot 18)\end{array}$ \\
\hline $\begin{array}{l}{\left[\mathrm{CuCu}(\mathrm{OX})_{2}\left(\mathrm{H}_{2} \mathrm{O}\right)_{4}\right]} \\
\mathrm{C}_{4} \mathrm{H}_{8} \mathrm{O}_{12} \mathrm{Cu}_{2}\end{array}$ & (10) & $375 \cdot 18$ & 77 & 320 & $2 \cdot 33$ & $\begin{array}{l}17 \cdot 15 \\
(16 \cdot 94)\end{array}$ & $\begin{array}{c}17 \cdot 23 \\
(16 \cdot 94)\end{array}$ & $\begin{array}{c}12 \cdot 62 \\
(12 \cdot 81)\end{array}$ & $\begin{array}{c}2 \cdot 03 \\
(2 \cdot 15)\end{array}$ \\
\hline
\end{tabular}

N.B: In column one, the numbers 1-10, enclosed within brackets, are the numbers assigned to the respective complexes. In the text, for the discussion of a particular complex, its corresponding number has been used. 
20-300 $\mathrm{K}$ temperature range at 6 and $8 \mathrm{kG}$ magnetic fields. The diamagnetic corrections were made by using Pascal constants.

\section{Results and discussion}

The oxalate-bridged bi-metallic assemblies were readily obtained by a one-pot reaction of a M(II) chloride, pota-

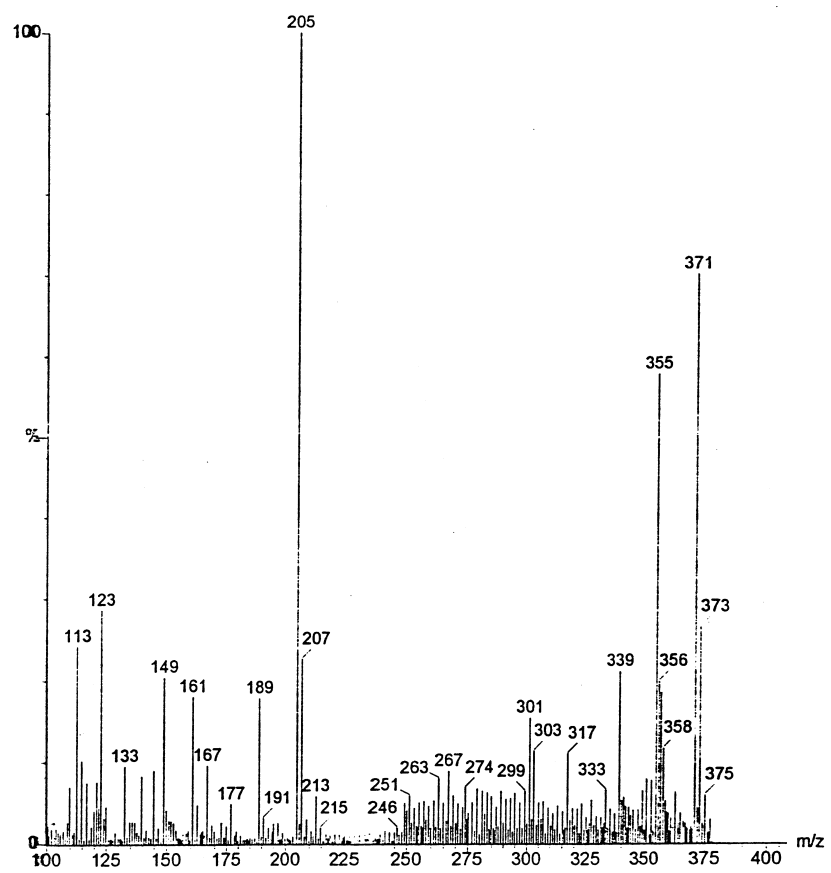

Figure 1a. ES mass spectrum of $\left[\mathrm{CuNi}(\mathrm{OX})_{2}\left(\mathrm{H}_{2} \mathrm{O}\right)_{4}\right]$.

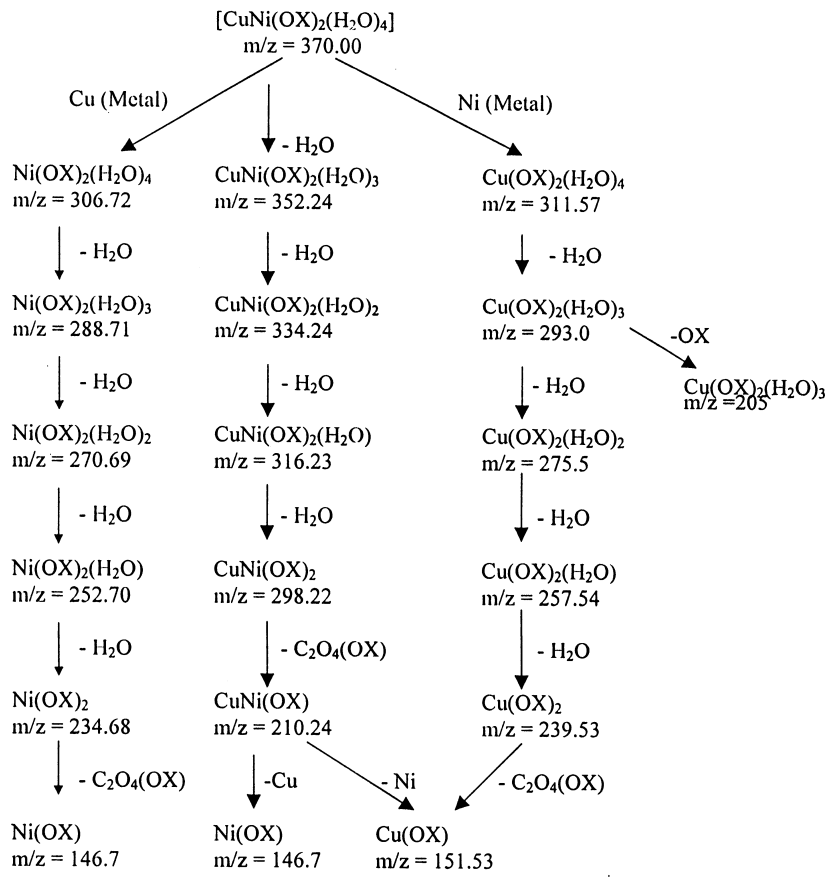

Figure 1b. Fragmentation pattern of $\left[\mathrm{CuNi}(\mathrm{OX})_{2}\left(\mathrm{H}_{2} \mathrm{O}\right)_{4}\right]$. ssium oxalate and $\mathrm{M}^{\prime}(\mathrm{II})$ salt in water at $90^{\circ} \mathrm{C}$. The complexes are insoluble in common organic solvents. Loss of water molecules at $150^{\circ} \mathrm{C}$ indicates their coordinate nature. The ES mass spectrum (figure 1a) of $\left[\mathrm{CuNi}(\mathrm{OX})_{2}\left(\mathrm{H}_{2} \mathrm{O}\right)_{4}\right]$ shows a base peak at $\mathrm{m} / z=205$ due to $\mathrm{Cu}(\mathrm{OX})\left(\mathrm{H}_{2} \mathrm{O}\right)_{3}$. The molecular ion peak appears at $m / z=371$. The fragmentation pattern of complex is shown in figure $1 \mathrm{~b}$. The chelated oxalate groups generally show an asymmetric $v(\mathrm{C}=\mathrm{O})$ vibration at 1700 and $\delta(\mathrm{CO})$ at ca $800 \mathrm{~cm}^{-1}$. In the infrared spectra (figures 2 and 3 ) of the complexes 1-10 (see table 1), the vibrations due to oxalate group appear at $1650-1610 \mathrm{~cm}^{-1}$ and $810-780 \mathrm{~cm}^{-1}$, respectively, indicating that the oxalate ions function as bridging moieties. The bonding of oxalate to metal ions is shown by the presence of bands at $520-490 \mathrm{~cm}^{-1}$ and $460-405 \mathrm{~cm}^{-1}$ due to $v(\mathrm{MO})+v(\mathrm{CC})$ and $v(\mathrm{MO})+\operatorname{ring}$ deformation modes, respectively. A band at $3400-3350 \mathrm{~cm}^{-1}$ in the IR spectra of the complexes, indicates presence of water molecule(s). The coordinated nature of water is inferred from the presence of IR bands at $725-710 \mathrm{~cm}^{-1}$ and $670-660 \mathrm{~cm}^{-1}$, which is assigned to the $\rho_{\mathrm{r}}\left(\mathrm{H}_{2} \mathrm{O}\right)$ and $\rho_{\mathrm{w}}\left(\mathrm{H}_{2} \mathrm{O}\right)$, respectively.

The bands appearing at $15385 \mathrm{~cm}^{-1}$ and $20000 \mathrm{~cm}^{-1}$ in the electronic spectrum of the complex 2 are attributed to

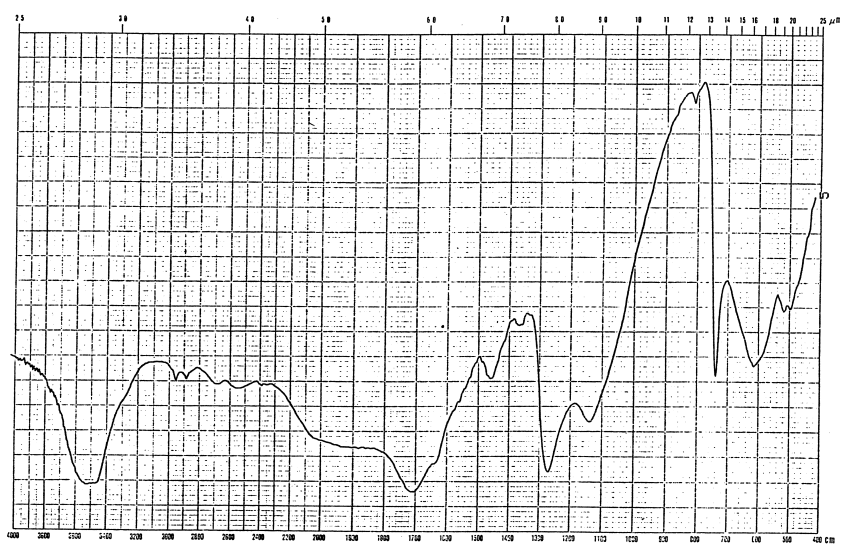

Figure 2. Infrared spectrum of oxalic acid $\left(\mathrm{H}_{2} \mathrm{C}_{2} \mathrm{O}_{4}\right)$.

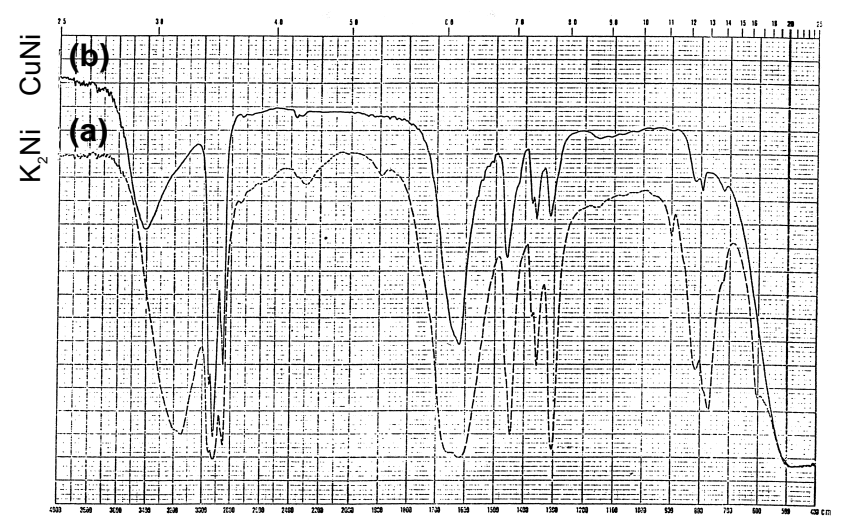

Figure 3. Infrared spectra of a. $\left[\mathrm{K}_{2} \mathrm{Ni}(\mathrm{OX})_{2}\left(\mathrm{H}_{2} \mathrm{O}\right)_{2}\right] \cdot 4 \mathrm{H}_{2} \mathrm{O}$; and b. $\left[\mathrm{CuNi}(\mathrm{OX})_{2}\left(\mathrm{H}_{2} \mathrm{O}\right)_{4}\right]$. 
${ }^{4} T_{1 \mathrm{~g}}(\mathrm{~F}) \rightarrow{ }^{4} A_{2 \mathrm{~g}}$ and ${ }^{4} T_{1 \mathrm{~g}}(\mathrm{~F}) \rightarrow{ }^{4} T_{1 \mathrm{~g}}(\mathrm{P})$ transitions, respectively, assuming an octahedral geometry. The spectrum of the complex 3 exhibits bands at $9216 \mathrm{~cm}^{-1}$, and $13793 \mathrm{~cm}^{-1}$, which are assigned to the ${ }^{3} A_{2 \mathrm{~g}}(\mathrm{~F}) \rightarrow{ }^{3} T_{2 \mathrm{~g}}(\mathrm{~F})$ and ${ }^{3} A_{2 g}(\mathrm{~F}) \rightarrow{ }^{3} T_{1 \mathrm{~g}}(\mathrm{~F})$ transitions, respectively, on the basis of an octahedral geometry. Only one absorption band observed at $14815 \mathrm{~cm}^{-1}$ in the spectrum of complex 4 is assigned to the ${ }^{2} E_{\mathrm{g}} \rightarrow{ }^{2} T_{2 \mathrm{~g}}(\mathrm{D})$ transition, which suggests octahedral arrangement of the ligand atoms around the metal ion. Three bands appear in the complex 6 at $9049 \mathrm{~cm}^{-1}, 15384 \mathrm{~cm}^{-1}$, and $19230 \mathrm{~cm}^{-1}$, which are

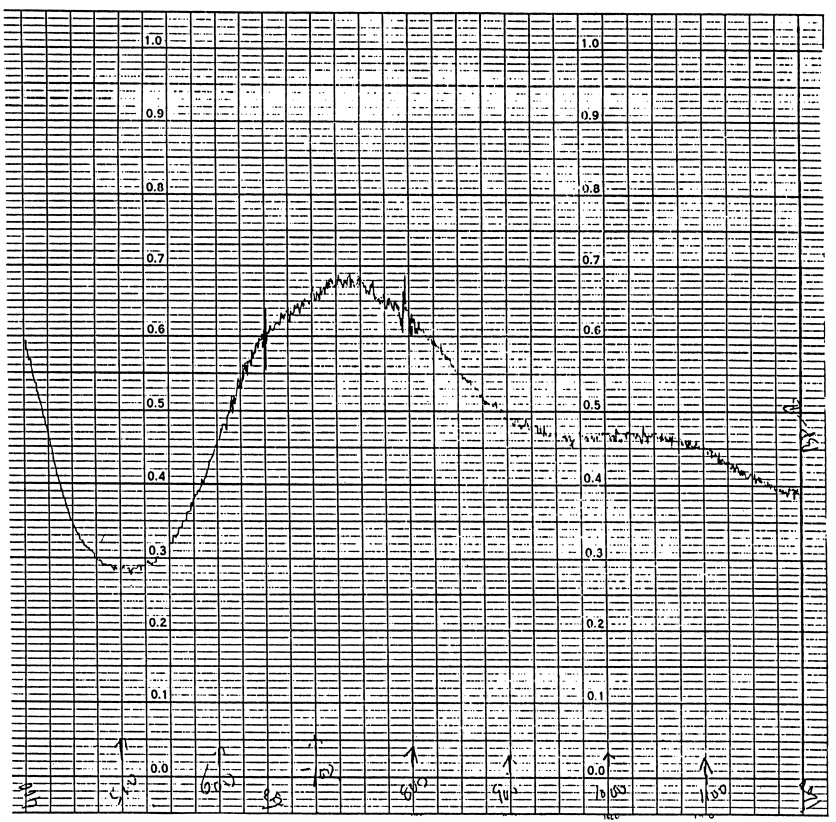

Figure 4. Electronic spectrum of $\left[\mathrm{NiNi}(\mathrm{OX})_{2}\left(\mathrm{H}_{2} \mathrm{O}\right)_{4}\right]$.

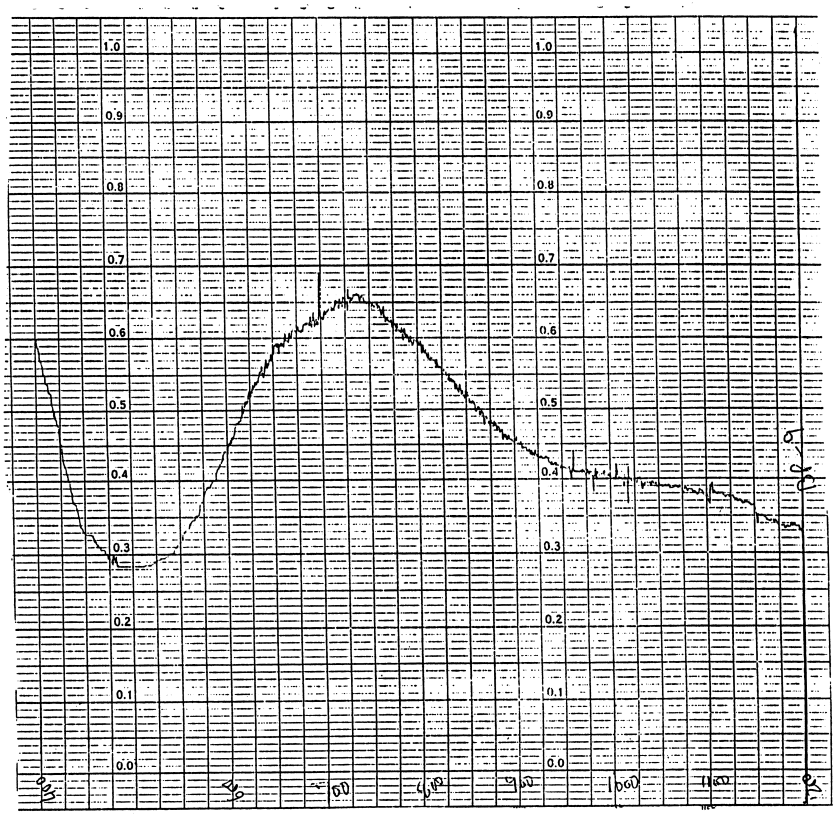

Figure 5. Electronic spectrum of $\left[\mathrm{CuNi}(\mathrm{OX})_{2}\left(\mathrm{H}_{2} \mathrm{O}\right)_{4}\right]$. assigned to the ${ }^{3} A_{2 \mathrm{~g}} \rightarrow{ }^{3} T_{2 \mathrm{~g}}$ transition of $\mathrm{Ni}(\mathrm{II})$ and ${ }^{4} T_{1 \mathrm{~g}}(\mathrm{~F}) \rightarrow{ }^{4} A_{2 \mathrm{~g}}$ and ${ }^{4} T_{1 \mathrm{~g}}(\mathrm{~F}) \rightarrow{ }^{4} T_{1 \mathrm{~g}}(\mathrm{P})$ transitions of $\mathrm{Co}(\mathrm{II})$, respectively, assuming octahedral geometry. The spectrum of complex 7 exhibits bands at $9302 \mathrm{~cm}^{-1}$ and $20000 \mathrm{~cm}^{-1}$, which are assigned to the ${ }^{4} T_{1 \mathrm{~g}}(\mathrm{~F}) \rightarrow{ }^{4} A_{2 \mathrm{~g}}$ and ${ }^{4} T_{1 \mathrm{~g}}(\mathrm{~F}) \rightarrow{ }^{4} T_{1 \mathrm{~g}}(\mathrm{P})$ transitions of $\mathrm{Co}(\mathrm{II})$, respectively. A band at $13885 \mathrm{~cm}^{-1}$ is attributed to ${ }^{2} E_{\mathrm{g}} \rightarrow{ }^{2} T_{2 \mathrm{~g}}(\mathrm{D})$ transition. These spectral features indicate an octahedral geometry around the metal ions. Two bands at $9523 \mathrm{~cm}^{-1}$ and $13513 \mathrm{~cm}^{-1}$ appearing in the spectrum (figure 4) of the complex 8 are attributed to ${ }^{3} A_{2 \mathrm{~g}} \rightarrow{ }^{3} T_{2 \mathrm{~g}}(\mathrm{~F})$ and ${ }^{3} A_{2 \mathrm{~g}}(\mathrm{~F}) \rightarrow{ }^{3} T_{1 \mathrm{~g}}(\mathrm{~F})$ transitions, respectively, showing an octahedral geometry. The complex 9 exhibited bands (figure 5) at $10101 \mathrm{~cm}^{-1}$ and $25974 \mathrm{~cm}^{-1}$, which are assigned to ${ }^{3} A_{2 \mathrm{~g}} \rightarrow{ }^{3} T_{2 \mathrm{~g}}(\mathrm{~F})$ and ${ }^{3} A_{2 \mathrm{~g}} \rightarrow{ }^{3} T_{1 \mathrm{~g}}(\mathrm{P})$ transitions of Ni(II), respectively. A band at $13605 \mathrm{~cm}^{-1}$ is assigned to ${ }^{2} E_{\mathrm{g}} \rightarrow{ }^{2} T_{2 \mathrm{~g}}$ (D) transition of $\mathrm{Cu}(\mathrm{II})$. These spectral features are characteristic of an octahedral stereochemistry around the metal ions. Only one absorption band at $14925 \mathrm{~cm}^{-1}$ in the spectrum of complex $\mathbf{1 0}$ is assigned to ${ }^{2} E_{\mathrm{g}} \rightarrow{ }^{2} T_{2 \mathrm{~g}}(\mathrm{D})$ transition which suggests octahedral stereochemistry around the metal ion. These features of electronic spectra are the characteristic of octahedral bonding of oxalate with metal ions. The ESR spectrum (figure 6) of the powder $\left[\mathrm{CuNi}(\mathrm{OX})_{2}\left(\mathrm{H}_{2} \mathrm{O}\right)_{4}\right]$ recorded at liquid nitrogen temperature shows a signal at $3090 \mathrm{G}$ yielding a $g$ value of 2.093 for copper(II), and a signal at $2830 \mathrm{G}$ yielding a $g$ value of 2.283 for nickel(II). This suggests magnetic interaction between the metal ions in the bi-metallic assembly.

\section{Magnetic properties}

The room temperature magnetic moments of complexes 1-10 are given in table 1 . The cryomagnetic properties of the bimetallic assemblies $\left[\mathrm{CuNi}(\mathrm{OX})_{2}\left(\mathrm{H}_{2} \mathrm{O}\right)_{4}\right]$ and $\left[\mathrm{NiNi}(\mathrm{OX})_{2}\left(\mathrm{H}_{2} \mathrm{O}\right)_{4}\right]$ were studied and the respective cryomagnetic behaviour is shown in figures 7 and 8 in the form of $\chi_{\mathrm{M}}$ vs $T, \chi_{\mathrm{M}}^{-1}$ vs $T, \chi_{\mathrm{M}} T$ vs $T$ and $\mu_{\mathrm{eff}}$ vs $T$ plots, where $\chi_{\mathrm{M}}$ is magnetic susceptibility per $M_{2}$ and $T$ is

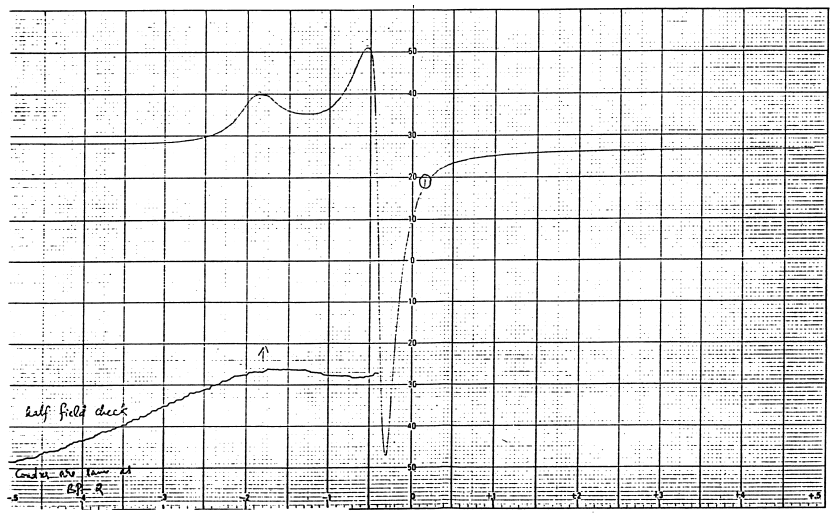

Figure 6. ESR spectrum of $\left[\mathrm{CuNi}(\mathrm{OX})_{2}\left(\mathrm{H}_{2} \mathrm{O}\right)_{4}\right]$. 
temperature in Kelvin. The magnetic moment, $\mu_{\mathrm{eff}}(\mathrm{BM})$ is calculated by using the equation,

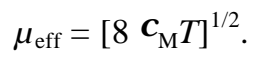

The magnetic susceptibility $1.54 \mathrm{~cm}^{3}$ of $\left[\mathrm{CuNi}(\mathrm{OX})_{2}\right.$ $\left.\left(\mathrm{H}_{2} \mathrm{O}\right)_{4}\right]$ at $6 \mathrm{kG}$ and $300 \mathrm{~K}$ results in the magnetic moment value of $3.51 \mu_{\mathrm{B}}$, which is lower than spin-only value of $3.87 \mu_{\mathrm{B}}$ for the magnetically dilute $\mathrm{Cu}(\mathrm{II})-\mathrm{Ni}$ (II) $\left[S_{\mathrm{Cu}}=1 / 2, S_{\mathrm{Ni}}=1\right]$ assembly. When the temperature is lowered, $\chi_{\mathrm{M}} T$ and $\mu_{\text {eff }}$ decrease and reach a plateau

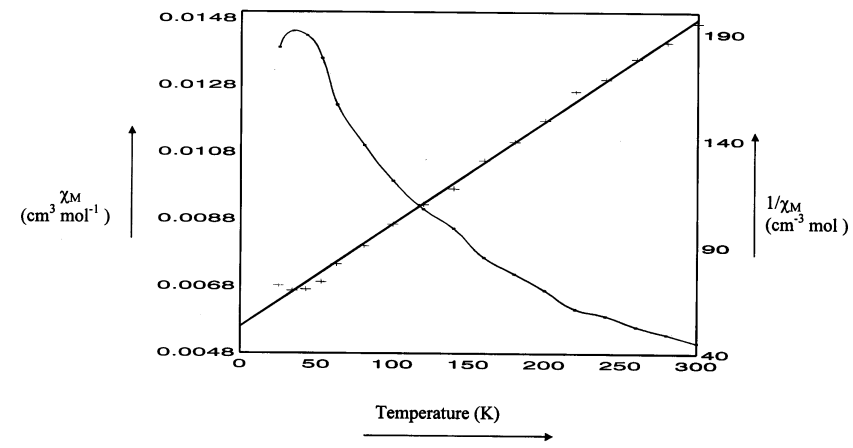

Figure 7a. Thermal variation of $\chi_{\mathrm{M}}(\cdot)$ and inverse susceptibility, $1 / \chi_{\mathrm{M}}(+)$ of complex $\left[\mathrm{CuNi}(\mathrm{OX})_{2}\left(\mathrm{H}_{2} \mathrm{O}\right)_{4}\right]$.

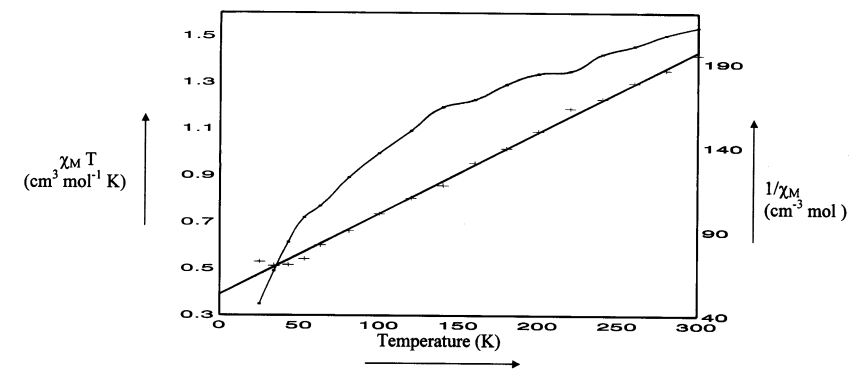

Figure 7b. Thermal dependence of $\chi_{\mathrm{M}} T$ and inverse susceptibility, $1 / \chi_{\mathrm{M}}(+)$ of complex $\left[\mathrm{CuNi}(\mathrm{OX})_{2}\left(\mathrm{H}_{2} \mathrm{O}\right)_{4}\right]$.

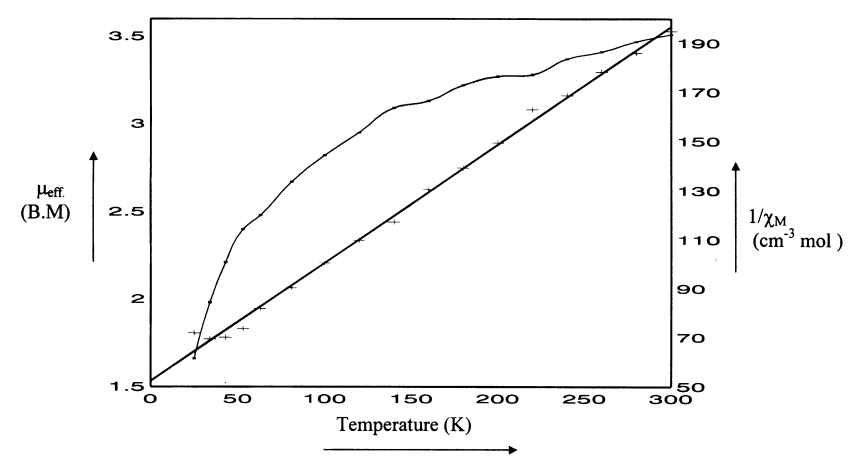

Figure 7c. Plot of the temperature dependence of the reciprocal magnetic susceptibility $(+)$ and magnetic moment $(\cdot)$ per $\mathrm{Cu}(\mathrm{II})-\mathrm{Ni}(\mathrm{II})$ for $\left[\mathrm{CuNi}(\mathrm{OX})_{2}\left(\mathrm{H}_{2} \mathrm{O}\right)_{4}\right]$. around $20 \mathrm{~K}$ with $\chi_{\mathrm{M}} T=0.3496 \mathrm{~cm}^{3} \mathrm{~mol}^{-1} \mathrm{~K}$ and $\mu_{\text {eff }}=$ $1.67 \mu_{\mathrm{B}}$. The magnetic susceptibility obeys the CurieWeiss law with Weiss constant of $-100 \mathrm{~K}$. The observed magnetic behaviour suggests the antiferromagnetic interaction within the assembly. The similar cryomagnetic magnetic behaviour is observed at $8 \mathrm{kG}$ magnetic field, indicating that it is field independent.

The complex $\left[\mathrm{NiNi}(\mathrm{OX})_{2}\left(\mathrm{H}_{2} \mathrm{O}\right)_{4}\right]$ exhibits magnetic susceptibility value of $1.585 \mathrm{~cm}^{3} \mathrm{~mol}^{-1}$ and magnetic moment $3.56 \mu_{\mathrm{B}}$ at $6 \mathrm{kG}$ and $300 \mathrm{~K}$. The magnetic moment value is lower than the spin-only value of $4.90 \mu_{\mathrm{B}}$

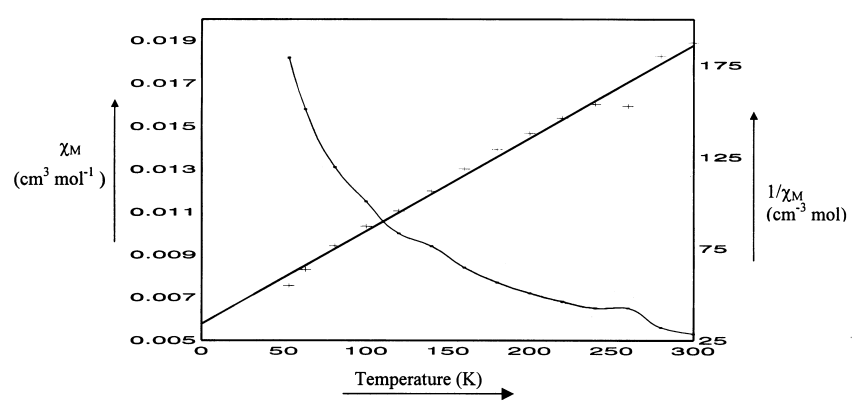

Figure 8a. Thermal variation of $\chi_{\mathrm{M}}(\cdot)$ and inverse susceptibility, $1 / \chi_{M}(+)$ of complex $\left[\mathrm{NiNi}(\mathrm{OX})_{2}\left(\mathrm{H}_{2} \mathrm{O}\right)_{4}\right]$.

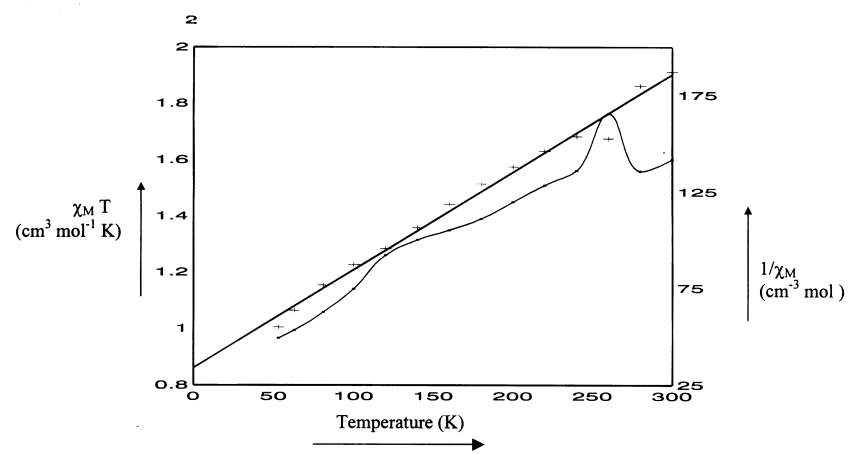

Figure 8b. Thermal dependence of $\chi_{\mathrm{M}} T(\cdot)$ and inverse susceptibility, $1 / \chi_{\mathrm{M}}(+)$ of complex $\left[\mathrm{NiNi}(\mathrm{OX})_{2}\left(\mathrm{H}_{2} \mathrm{O}\right)_{4}\right]$.

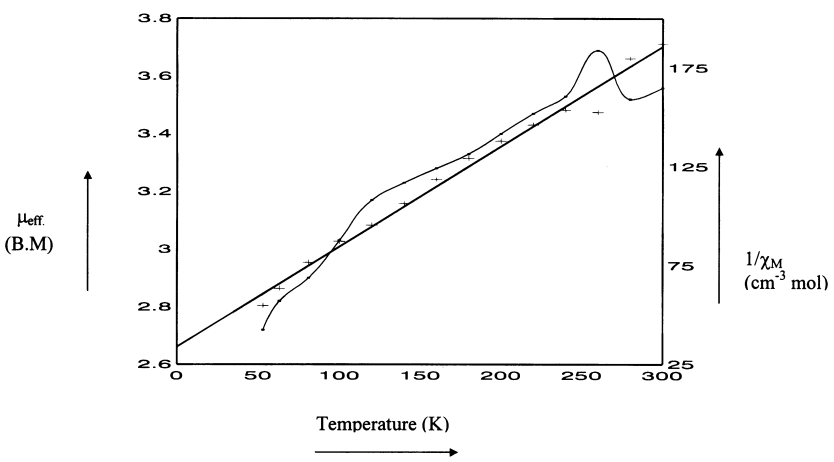

Figure 8c. Plot of the temperature dependence of the reciprocal magnetic susceptibility (+) and magnetic moment $(\cdot)$ per $\mathrm{Ni}(\mathrm{II})-\mathrm{Ni}(\mathrm{II})$ for $\left[\mathrm{NiNi}(\mathrm{OX})_{2}\left(\mathrm{H}_{2} \mathrm{O}\right)_{4}\right]$. 


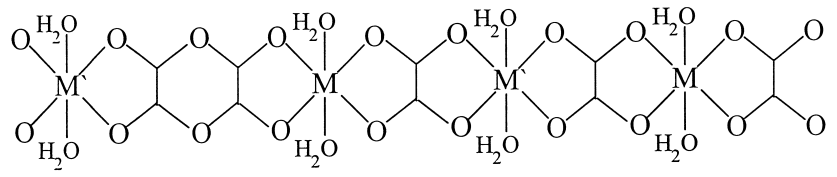

Figure 9. Schematic representation of the ox-bridged network: structure of $\mathrm{M}-\mathrm{OX}-\mathrm{M}^{\prime}\left[\mathrm{M}=\mathrm{M}^{\prime}=\mathrm{Mn}^{\mathrm{II}}, \mathrm{Co}^{\mathrm{II}}, \mathrm{Ni}^{\mathrm{II}}\right.$ and $\mathrm{Cu}^{\mathrm{II}}$.

for the magnetically dilute $\mathrm{Ni}(\mathrm{II})-\mathrm{Ni}(\mathrm{II})\left(S_{\mathrm{Ni}}=1, S_{\mathrm{Ni}}=1\right)$ assembly. On lowering the temperature $\chi_{\mathrm{M}} T$ decreases and it shows a value $0.932 \mathrm{~cm}^{3} \mathrm{~mol}^{-1} \mathrm{~K}$ yielding the $\mu_{\text {eff }}=$ $2.78 \mu_{\mathrm{B}}$ at $50 \mathrm{~K}$. The magnetic susceptibility obeys the Curie-Weiss law in the 50-300 K temperature range with a Weiss constant of $-50 \mathrm{~K}$. The same cryomagnetic behaviour is observed at $8 \mathrm{kG}$ magnetic field also which implies presence of the antiferromagnetic interaction between $\mathrm{Ni}(\mathrm{II})-\mathrm{Ni}(\mathrm{II})$ ions.

On the basis of the above studies the structure proposed for the oxalate-bridged molecular assembly is shown in figure 9.

\section{Acknowledgements}

We thank the Head, Chemistry Department, Banaras Hindu University, for providing laboratory facilities. The cryomagnetic measurement facility provided by Prof. R N Mukherjee, Chemistry Department, IIT, Kanpur is gratefully acknowledged. Recording of ES mass spectra (CDRI, Lucknow) and ESR spectra (RSIC, IIT, Bombay) are also acknowledged. One of us (BPS) would like to thank the CSIR, New Delhi, for the award of a senior research fellowship.

\section{References}

Atovmyan L O, Shilov G V, Lyubovskaya R N, Zhilyaeva E I, Ovanesyan N S, Piramova S I and Gusakovskaya I G 1993 JETP Lett. 58766

Bellitto C and Day P 1992 J. Mater. Chem. 2265

Descurtins S, Schmalle H W, Oswald H R, Linden A, Ensling J, Gutlich P and Hauser A 1994a Inorg. Chim. Acta 21665

Descurtins S, Schmalle H W, Schnewewly P, Oswald H R, Linden A, Ensling J and Gutlich P 1994b J. Am. Chem. Soc. 1169521

Goodenough J B 1963 Magnetism and the chemical bond (New York: Interscience)

Julve M, Faus J, Verdaguer M and Gleizes A $1984 \mathrm{~J}$. Am. Chem. Soc. 1068306

Kahn O 1993 Molecular magnetism (New York: VCH)

Kahn O 1995 Adv. Inorg. Chem. 43179

Miller J S and Epstein A J 1994 Angew. Chem. Int. Ed. Engl. 33 385

Miller J S, Calabrese J C, Epstein A J, Bigelow R W, Zang J H and Reilt W M 1986 J. Chem. Soc. Chem. Commun. 1026

Miller J S, Epstein A J and Reilt W M 1988a Acc. Chem. Res. 21 114-120

Miller J S, Epstein A J and Reilt W M 1988b Chem. Res. 85 201

Nakaozawa Y, Tamura M, Shirakawa N, Shiomi D, Takahashi M, Kinoshita M and Ishikawa M 1992 Phys. Rev. B46 8906

Pei Y, Verdaguer M, Kahn O, Slelten J and Renard J P 1986 J. Am. Chem. Soc. 108428

Pei Y, Joumeax Y and Kahn O 1989 Inorg. Chem. 28100

Tanaki H, Zhong Z J, Matsumoto N, Kida S, Koikawa N, Achiwa Y, Hashimoto Y and Okawa H 1992 J. Am. Chem. Soc. 1146974 